\title{
Desiccation tolerance in Dendroligotrichum dendroides (Brid. ex Hedw.) Broth. from two Chilean populations with contrasting precipitation
}

\section{Tolerancia a la desecación en Dendroligotrichum dendroides (Brid. ex Hedw.) Broth. de dos poblaciones de Chile con precipitación contrastante}

\author{
Cristian Atala ${ }^{1 *}$, Juan Felipe Alfaro ${ }^{1}$, María José Parra ${ }^{2} \&$ Alfredo Saldaña ${ }^{3}$ \\ ${ }^{1}$ Laboratorio de Anatomía y Ecología Funcional de Plantas (AEF), Instituto de Biología, Facultad de Ciencias, Pontificia \\ Universidad Católica de Valparaíso, Campus Curauma, Valparaíso, Chile. \\ Universidad San Sebastián, Facultad de Ciencias, Departamento de Ciencias Biológicas y Químicas, Cruz 1577, Concepción, \\ Chile. \\ ${ }^{3}$ Departamento de Botánica, Facultad de Ciencias Naturales y Oceanográficas, Universidad de Concepción, Chile. \\ *cristian.atala@ucv.cl
}

\begin{abstract}
Mosses are poikilohydrous non-vascular plants, usually with some degree of desiccation tolerance. Dendroid mosses have conducting tissues that make them analogous to vascular plants. Functional studies on these mosses, however, are scarce. Dendroligotrichum dendroides is a dendroid moss that occurs in Chile in the understory of temperate forests where it can be exposed to summer drought. We studied desiccation tolerance and rehydration capacity on $D$. dendroides from two populations with contrasting precipitation. We sampled plants from the northern part of their distribution (Contulmo, Araucanía district; lower precipitation), and from a southern population in Katalapi (Los Lagos district; higher precipitation). We measured relative water content and maximum efficiency of the PSII $\left(\mathrm{F}_{\mathrm{v}} / \mathrm{F}_{\mathrm{m}}\right)$ in plants exposed to desiccation and rehydration. Plants from both populations showed desiccation tolerance and were able to recover their $\mathrm{F}_{\mathrm{v}} / \mathrm{F}_{\mathrm{m}}$ after rehydration. However, the northern population lost water more slowly and recovered the $\mathrm{F}_{\mathrm{v}} / \mathrm{F}_{\mathrm{m}}$ to higher values compared to the southern population. The northern population can be exposed to summer droughts. The southern population receives rain throughout the year. These differences could be attributed to local adaptation to the precipitation regimens of each site. Further studies are needed to unveil the physiological and biochemical mechanisms underlying the desiccation tolerance of $D$. dendroides.
\end{abstract}

KEYWORDS: Dendroligotrichum dendroides, dendroid moss, desiccation tolerance, $\mathrm{F}_{\mathrm{v}} / \mathrm{F}_{\mathrm{m}}$.

\section{RESUMEN}

Los musgos son plantas no vasculares poiquilohídricas, usualmente con algún grado de tolerancia a la desecación. Los musgos dendroides tienen tejidos conductores que los hacen análogos a las plantas vasculares. Sin embargo, los estudios funcionales en estos musgos son escasos. Dendroligotrichum dendroides es un musgo dendroide que crece en Chile en el sotobosque del bosque templado, donde puede exponerse a sequía estival. En este trabajo se estudia la tolerancia a la desecación y la capacidad de rehidratación en $D$. dendroides de dos poblaciones con diferente precipitación. Muestreamos plantas de la parte norte de su distribución (Contulmo, Región de la Araucanía; baja precipitación), y de la parte sur en Katalapi (Región de Los Lagos; alta precipitación). Se midió el contenido relativo de agua y la eficiencia máxima del PSII $\left(\mathrm{F}_{\mathrm{v}} / \mathrm{F}_{\mathrm{m}}\right)$ en plantas expuestas a desecación y rehidratación. Las plantas de ambas poblaciones mostraron tolerancia a la desecación y fueron capaces de recuperar el $\mathrm{F}_{\mathrm{v}} / \mathrm{F}_{\mathrm{m}}$ luego de la rehidratación. Sin embargo, la población del norte perdió agua más lento y recuperó su $\mathrm{F}_{\mathrm{v}} / \mathrm{F}_{\mathrm{m}}$ a valores mayores comparado con la población del sur. La población norte puede estar expuesta a períodos de sequía en verano. La población del sur recibe lluvia durante todo el año. Estas diferencias podrían atribuirse a adaptación local a los distintos regímenes de precipitación de cada sitio. Más estudios se requieren para entender los mecanismos fisiológicos y bioquímicos que subyacen la tolerancia a la desecación en $D$. dendroides.

Palabras clave: Dendroligotrichum dendroides, musgos dendroides, tolerancia a la desecación, $\mathrm{F}_{\mathrm{v}} / \mathrm{F}_{\mathrm{m}}$. 


\section{INTRODUCTION}

Most bryophyte species are considered poikilohydric organisms because they present a rudimentary control of water loss and depend on environmental humidity (Kappen \& Valladares 2007). Mosses usually are able to tolerate desiccation and return to full metabolic activity briefly after rehydration (Proctor et al. 2007a, 2007b, Waite \& Sack 2010). Desiccation tolerance (DT) is the ability to dry equilibrating plant tissues with air that is moderately to extremely dry and then regain normal function after rehydration (sensu Alpert 2005). Many moss species are able to lose $90-95 \%$ of their water, resulting in a physiological state with no liquid phase in their cells, but they can return to normal metabolism and growth short after rehydration (Tuba et al. 1998, Alpert 2000). Despite the many studies regarding DT in mosses, few studies address the possible underlying mechanisms (Proctor et al. 2007b). After 90 $\%$ water loss or more, desiccation-tolerant plants seem to be absolutely dry and its survival depends on: 1 . Limit the cellular damage to a reparable level, 2. Maintain structural and physiological integrity of cells during desiccation, and 3 . Repair cellular damage rapid and efficiently during rehydration (Oliver 1996, Rascio \& La Roca 2005, Proctor et al. 2007b, Pressel \& Duckett 2010). Among the species that show DT, some like Syntrichia ruralis can withstand a very fast desiccation (Oliver \& Bewley 1997, Oliver et al. 2000). Other species like Physcomitrella patens and Fontinalis antipyretica can survive prolonged periods of desiccation only if the dehydration rate is slow (Wang et al. 2009, Cruz de Carvalho et al. 2011, 2012).

Most bryophytes do not possess morphological or physiological mechanisms to retain or control water as efficiently as tracheophytes (Proctor 1981). Thus, their hydric status is rapidly balanced with the water potential of the environment (Proctor et al. 1998). This means that they can be dehydrated in a few minutes, and, in some species, remain in the desiccated state for over 20 years without losing viability (Alpert 2000). Rehydration occurs in minutes, showing total recovery of cellular functions in a few hours (Csintalan et al. 1998). The ability of these plants to tolerate rapid desiccation suggests a constitutive component in the protection mechanism, although evidence of inducible components has been also found for some species (Cruz de Carvalho et al. 2011, Stark et al. 2013). This mechanism could involve large quantities of solutes in the hydrated tissues to maintain cellular stability during desiccation (Oliver et al. 1998). These solutes correspond mainly to sugars and proteins, like sucrose and dehydrins, which content seem to remain unaltered during desiccation (Oliver et al. 1998) although recently many protective proteins have been shown to increase during the dehydration process (Wang et al. 2009, Cui et al. 2012, Cruz de Carvalho et al. 2014). Antioxidant and photoprotective mechanisms also participate in the recovery, particularly of photosynthesis, of desiccated mosses after rehydration (Beckett et al. 2000, Beckett 2001, Lüttge et al. 2008). In most plants, dehydration results in a drop in all physiological processes. In mosses, photosynthesis is negatively impacted by a rapid drop in water content (Cui et al. 2009). Fluorescence measurements have been shown to correlate with the overall status of plant's photosynthetical apparatus (Maxwell \& Johnson 2000, Lambers et al. 2008). The maximum quantum yield of PSII $\left(\mathrm{F}_{\mathrm{v}} / \mathrm{F}_{\mathrm{m}}\right)$ and electron transport rate (ETR) have been shown to decrease as water content drop (Proctor 2010). Desiccation-tolerant plants, like Hymenophyllum spp. (Hymenophyllaceae, Pteridophyta), show a very close relationship between $\mathrm{F}_{\mathrm{v}} / \mathrm{F}_{\mathrm{m}}$ and water content both when dehydrated and rehydrated (María José Parra, unpublished data). When rehydrated, the short-time recovery rate of the $\mathrm{F}_{\mathrm{v}} / \mathrm{F}_{\mathrm{m}}$ of desiccation-tolerant species can be very fast. In some bryophyte species, the $\mathrm{F}_{\mathrm{v}} / \mathrm{F}_{\mathrm{m}}$ can reach $50 \%$ of maximum value within 0.1-0.5 seconds after rehydration (Proctor 2001, Proctor \& Pence 2002). When rehydrated, the $F_{v} / F_{m}$ recovery of desiccation-tolerant plants follows a logistic curve and inter- and intra-specific comparison can be made regarding the slope, asymptote and half-recovery time (Proctor 2010). The use of field plants, however, may alter fluorescence measurements due to hardening of plants.

Despite the complexity of the mosses belonging to Polytrichaceae, functional studies are scarce, and for some species non-existent (but see Longton 1981, Proctor 2000, 2001, 2010, Proctor et al. 2007a, 2007b). Recent studies on Dendroligotrichum dendroides (Brid. ex Hedw.) Broth. (Polytrichaceae) show that this moss can reach specific hydraulic conductivities (Ks) comparable to some woody angiosperms (Atala 2011). The "vascular" tissue of this moss optimizes hydraulic conductivity per unit of vascular tissue and shows acropetal conduit tapering, as many "true" vascular plants do (Atala \& Alfaro 2012). This moss grows up to more than $60 \mathrm{~cm}$ in height (CONC herbarium samples) and can be abundant in the understory of the temperate forest in Chile. Thus, this moss could be functionally considered as a vascular plant, and its behavior when desiccation could differ from "traditional" (and more studied) mosses. D. dendroides is found in Chile from Arauco Province to Magallanes (He 1998). It grows forming a stratum where it co-exists with seedlings of vascular plants and other mosses. In the northern-most part of its distribution it can experience seasonal desiccation, particularly in spring and summer, when precipitation is scarce (Di Castri \& Hajek 1976). In this context, it might be expected in populations of $D$. dendroides to show differences in the degree of DT, which can reflect the functional ability of this moss species to establish in a wide latitudinal and climatic range in Chile. Hence, we selected $D$. dendroides to study DT in tall and complex 
dendroid mosses with central strand of conducting tissue measuring fluorescence $\left(\mathrm{F}_{\mathrm{v}} / \mathrm{F}_{\mathrm{m}}\right)$ as the plant desiccates and rehydrates. Two populations with contrasting precipitation were selected. This moss species represent an intermediate state between small bryophytes and vascular plants both in size and anatomy (Atala 2011, Atala \& Alfaro 2012). While small mosses are affected mainly by surface tension, larger plants are affected largely by gravity (Proctor et al. 2007b). D. dendroides can conduct water internally (Atala 2011), but is still dependent on surface water. This moss forms cushion-like clusters, which reduce water loss (Proctor et al. 2007b). We hypothesize that this moss species can withstand desiccation but population differences in DT should be found, with the northern population showing higher DT.

\section{MATERIALS AND METHODS}

Plant MATERIAL AND STUdy SITES

Individuals of Dendroligotrichum dendroides were collected from Contulmo National Monument (38 $01^{\prime} \mathrm{S}$ $\left.73^{\circ} 10^{\prime} \mathrm{W}\right)$, located in the border between the Bio-Bio and Araucanía districts, and from Katalapi Private Park ( $41^{\circ} 31^{\text {' }}$ $\mathrm{S}-72^{\circ} 45^{\prime} \mathrm{W}$, Pichiquillaipe, Quillaipe Mountain Range) in the Los Lagos district. Both sites receive contrasting precipitation with Contulmo averaging $1400 \mathrm{~mm}$ per year and Katalapi between 2000-2200 mm per year (Di Castri \& Hajek 1976). In Contulmo, precipitation is more frequent in the winter, with dry summers during which periods of 2-4 weeks without rain are common (Di Castri \& Hajek 1976). In Katalapi, precipitations occur throughout the year (Di Castri \& Hajek 1976, Parra et al. 2012).

Collected plants were hydrated and healthy individuals. After collection in the field plants were kept moist at all times and were transported to the greenhouse after 1-2 days. They were kept in the greenhouse for 4-6 weeks before the desiccation-rehydration experiment. In the greenhouse they were partially shaded by a black plastic mesh and were watered daily by an automatic watering system that applied water as mist.

\section{DESICCATION-REHYDRATION EXPERIMENTS}

Ten adult individuals per site were taken to a greenhouse at Universidad de Concepción for the desiccation-rehydration cycles. All individuals were $15-20 \mathrm{~cm}$ tall. These individuals were put in open Petri dishes in a dark room and their weight was monitored with an analytical scale. Plants were fully hydrated at the start of the experiment, i.e. they were put in water for $10 \mathrm{~min}$ or more until a constant weight was reached. The maximal efficiency of the PSII $\left(\mathrm{F}_{\mathrm{v}} / \mathrm{F}_{\mathrm{m}}\right)$ was used as an indicator of the plant physiological status and was measured with a fluorimeter (Pocket PEA, Hansatech Instruments
Limited, UK) every 5 min for 2 hours. Plants were darkadapted for 45 min previous to the measurements of $\mathrm{F}_{\mathrm{v}} / \mathrm{F}_{\mathrm{m}}$. After 18 hours of desiccation, plants were rehydrated and the $\mathrm{F}_{\mathrm{v}} / \mathrm{F}_{\mathrm{m}}$ and weight were measured as stated early until initial water content was reached.

Relative water content (RWC) in time was recorded to address the desiccation-rehydration of the plants and was calculated as:

$\mathrm{RWC}=(($ fresh weight - dry weight $) /($ turgid weight- dry weight) $) * 100$

From the $\mathrm{F}_{\mathrm{v}} / \mathrm{F}_{\mathrm{m}}$ and $\mathrm{RWC}$ curves we also estimated: initial $\mathrm{F}_{\mathrm{v}} / \mathrm{F}_{\mathrm{m}}, \mathrm{RWC}_{50}, \mathrm{~F}_{\mathrm{v}} / \mathrm{F}_{\mathrm{m} 50}$, desiccation slope, rehydration slope, and final $\mathrm{F}_{\mathrm{v}} / \mathrm{F}_{\mathrm{m}} \cdot \mathrm{RWC}_{50}$ and $\mathrm{F}_{\mathrm{v}} / \mathrm{F}_{\mathrm{m} 50}$ correspond to the time at which $50 \%$ of RWC and initial $\mathrm{F}_{\mathrm{v}} / \mathrm{F}_{\mathrm{m}}$ has been reached, respectively. Desiccation and rehydration slopes were calculated using the linear portions of the RWC curves when desiccating and rehydrating, respectively. The linear portions usually included 5 points (measures). These traits were calculated for each individual and average values per population were used ( $n=10$ per population). Differences between populations were evaluated using a t-test. Data was normally distributed (Shapiro-Wilk W test, $\mathrm{p}<0.05$ ).

\section{RESULTS}

Dendroligotrichum dendroides individuals from both populations showed DT and recovered after rehydration (Fig. 1). The $\mathrm{F}_{\mathrm{v}} / \mathrm{F}_{\mathrm{m}}$ closely followed the RWC of plants (Fig. $1,2) . F_{v} / F_{m}$ rapidly dropped in the first hour of desiccation reaching values close to 0.4 . There were no differences between populations in $\mathrm{F}_{\mathrm{v}} / \mathrm{F}_{\mathrm{m}}$ of fully hydrated plants (Table I t-test, $\mathrm{p}>0.05)$. Similarly, we did not find population differences in the time at which the $50 \%$ of the $\mathrm{F}_{\mathrm{v}} / \mathrm{F}_{\mathrm{m}}$ was reached (Table I, t-test, $\mathrm{p}>0.05$ ). After rehydration, $\mathrm{F}_{\mathrm{v}} / \mathrm{F}_{\mathrm{m}}$ in both populations recovered rapidly (Fig 1). However, we found that plants from Contulmo were able to reach a higher $\mathrm{F}_{\mathrm{v}} / \mathrm{F}_{\mathrm{m}}$ after rehydration compared to plants from Katalapi (Table I, t-test, $\mathrm{p}<0.05$ ).

Plants reached less than $20 \%$ of their RWC after 2 hours and were able to reach $100 \%$ RWC after rehydration (Fig. 2). Plants from both populations dehydrated rapidly, but plants from Katalapi lost water faster than plants from Contulmo (Table I, t-test, $\mathrm{p}<0.05$ ). We found population differences in the time at which the $50 \%$ of the RWC was reached $\left(\mathrm{RWC}_{50}\right)$. Plants from Katalapi reached the $\mathrm{RWC}_{50}$ earlier (higher dehydration rate) than plants from Contulmo (Table I, t-test, $\mathrm{p}<0.05$ ). After rehydration, $\mathrm{RWC}$ in both populations increased to $100 \%$ within an hour (Fig 2). Plants from both populations rehydrated at a similar speed (Table I, t-test, $\mathrm{p}>0.05$ ). 
CONTULMO

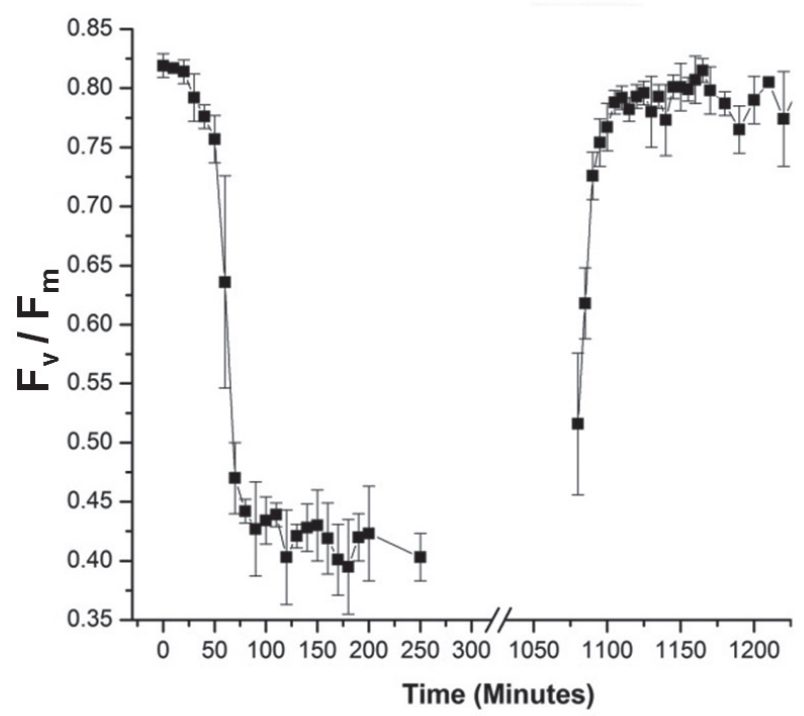

KATALAPI

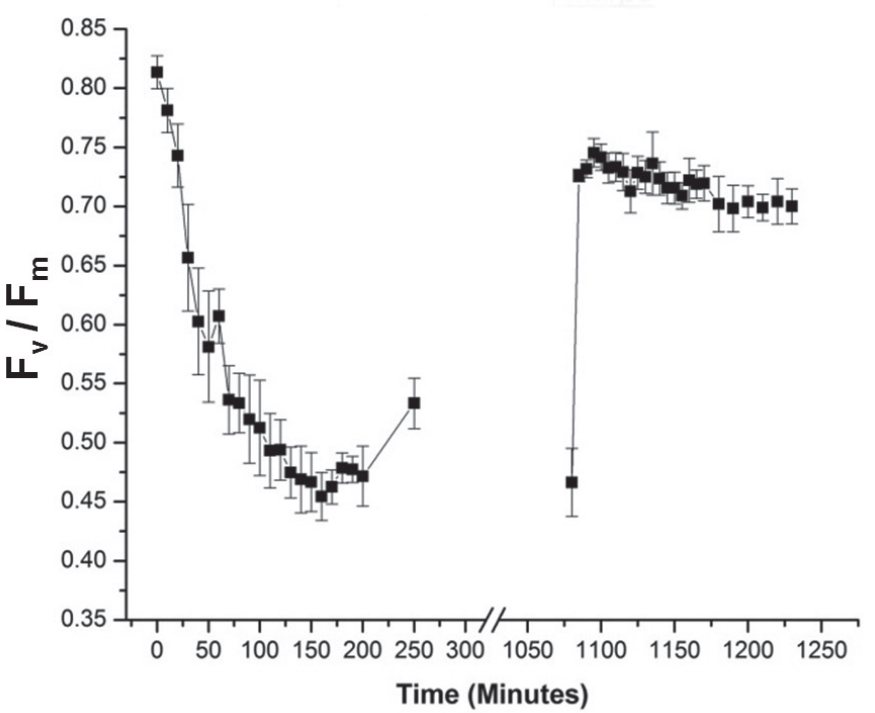

FIGURE 1. Maximum efficiency of the PSII $\left(\mathrm{F}_{\mathrm{v}} / \mathrm{F}_{\mathrm{m}}\right)$ of Dendroligotrichum dendroides plants from Contulmo (dryer) and Katalapi (moister) populations exposed to desiccation and rehydration ( $\mathrm{n}=10$ individuals per population).

FIgURA 1. Eficiencia máxima del PSII $\left(\mathrm{F}_{\mathrm{v}} / \mathrm{F}_{\mathrm{m}}\right)$ de plantas de Dendroligotrichum dendroides de poblaciones de Contulmo (seco) y Katalapi (húmedo) expuestas a desecación y rehidratación ( $\mathrm{n}=10$ individuos por población).
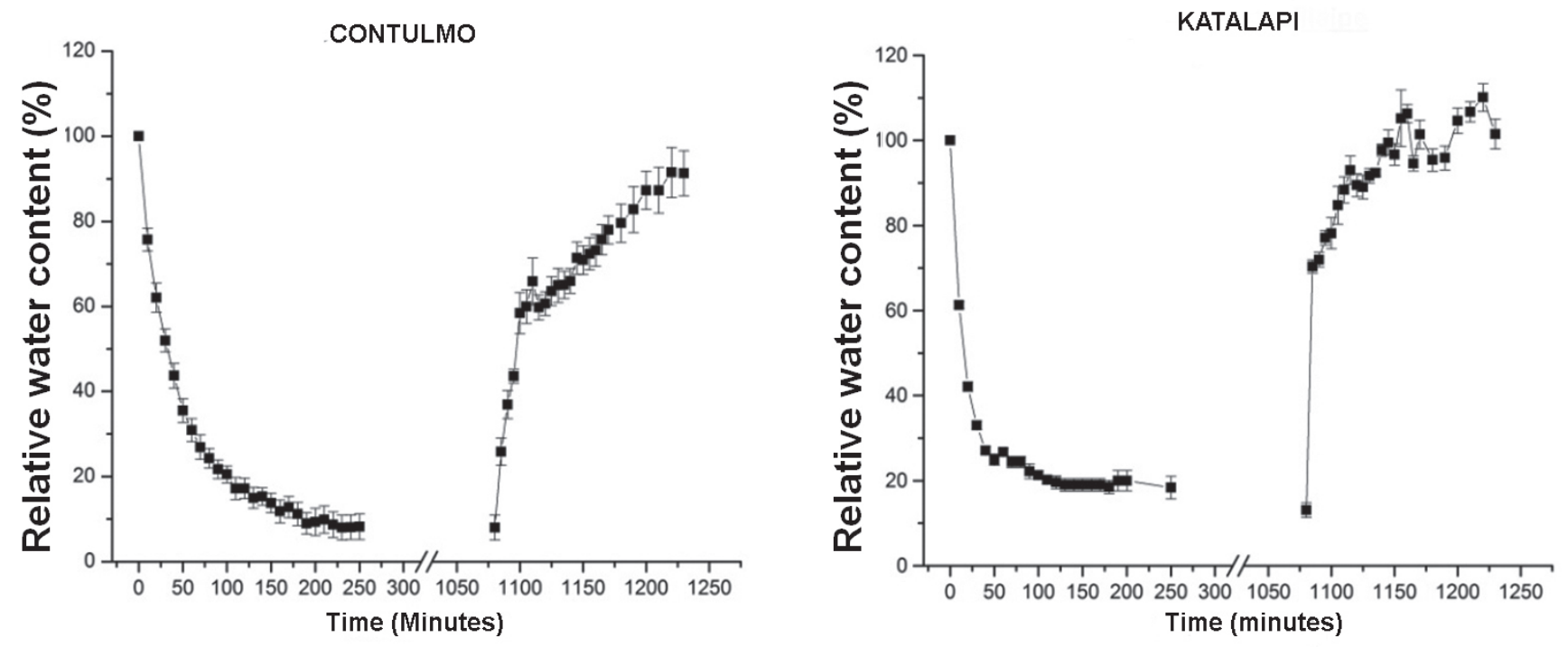

FIGURE 2. Relative water content (RWC) of Dendroligotrichum dendroides plants from Contulmo (dryer) and Katalapi (moister) populations exposed to desiccation and rehydration ( $\mathrm{n}=10$ individuals per population).

Figura 2. Contenido relativo de agua (CRA o RWC) de plantas de Dendroligotrichum dendroides de poblaciones de Contulmo (seco) y Katalapi (húmedo) expuestas a desecación y rehidratación ( $\mathrm{n}=10$ individuos por población). 
TABLE I. Desiccation and rehydration curves parameters of Dendroligotrichum dendroides individuals from two populations with contrasting precipitation frequency. $\mathrm{F}_{\mathrm{v}} / \mathrm{F}_{\mathrm{m} 50}=$ time to reach $50 \%$ of initial $\mathrm{F}_{\mathrm{v}} / \mathrm{F}_{\mathrm{m}}, \mathrm{RWC}_{50}=$ time to reach $50 \%$ of initial RWC (relative water content). Desiccation and rehydration slopes correspond to the slope of the linear portion of the $\mathrm{F}_{\mathrm{v}} / \mathrm{F}_{\mathrm{m}}$ curves. Sample size $=10$ plants per population. $P$ indicates the result of the t-test. Significant differences $(\mathrm{p}<0.05)$ in bold.

TABLA I. Parámetros de las curvas de desecación y rehidratación de individuos de Dendroligotrichum dendroides de dos poblaciones con frecuencias de precipitación contrastantes. $\mathrm{F}_{\mathrm{v}} / \mathrm{F}_{\mathrm{m} 50}=$ tiempo para alcanzar el $50 \%$ del valor inicial de $\mathrm{F}_{\mathrm{v}} / \mathrm{F}_{\mathrm{m}}, \mathrm{CRA}_{50}=$ tiempo para alcanzar el $50 \%$ del contenido relativo de agua inicial. Las pendientes de desecación y rehidratación corresponden a la pendiente de la regresión de la porción linear de las curvas de $\mathrm{F}_{\mathrm{v}} / \mathrm{F}_{\mathrm{m}}$. Tamaño muestreal $=10$ plantas por población. $P$ indica el resultado del test de t. Las diferencias significativas $(\mathrm{p}<0.05)$ se muestran en negrita.

\begin{tabular}{|c|c|c|c|c|c|c|}
\hline Population & $\begin{array}{l}\text { INITIAL } \\
\mathrm{F}_{\mathrm{v}} / \mathrm{F}_{\mathrm{M}} \\
\end{array}$ & $\begin{array}{l}\mathrm{F}_{\mathrm{v}} / \mathrm{F}_{\mathrm{M} 50} \\
(\mathrm{~min})\end{array}$ & $\mathrm{RWC}_{50}(\min )$ & DESICCATION SLOPE & REHYDRATION SLOPE & $\begin{array}{c}\text { MAX F }_{\mathrm{v}} / \mathrm{F}_{\mathrm{M}} \text { AFTER } \\
\text { REHYDRATION }\end{array}$ \\
\hline Contulmo & $0.819 \pm 0.014$ & $8.87 \pm 3.55$ & $3.68 \pm 0.76$ & $-1.3 \pm 0.5$ & $0.013 \pm 0.004$ & $0.790 \pm 0.028$ \\
\hline Katalapi & $0.813 \pm 0.031$ & $5.372 \pm 2.11$ & $1.58 \pm 0.26$ & $-5.1 \pm 1.7$ & $0.011 \pm 0.001$ & $0.723 \pm 0.028$ \\
\hline$P$ & 0.7454 & 0.095 & 0.0004 & 0.016 & 0.5467 & 0.006 \\
\hline
\end{tabular}

\section{DISCUSSION}

As it was hypothesized, this moss species showed population differences in the functional responses related to DT, with the northern population reaching a higher $\mathrm{F}_{\mathrm{v}} / \mathrm{F}_{\mathrm{m}}$ after rehydration and losing water more slowly compared to plants from the southern population. There were no obvious morphological differences between plants from the two populations. Also, in plants from Contulmo (dryer site), the $\mathrm{F}_{\mathrm{v}} / \mathrm{F}_{\mathrm{m}}$ dropped more slowly as plant desiccated compared to individuals from Katalapi (moister site). Many moss species show some degree of DT (Proctor et al. 2007a, 2007b). However, most of the studied mosses are a few centimeters tall and lack specialized conductive tissues. We found that Dendroligotrichum dendroides, a dendroid moss that can reach $60 \mathrm{~cm}$ tall and has a central strand of "vascular" tissue (Atala \& Alfaro 2012), can also tolerate desiccation (Fig. 1). Additionally, this moss is ecologically different to other mosses in Chile since it can form tall cushion-like clusters in the understory of the temperate forest where it coexist with vascular plants like Nertera granadensis and ferns like Lophosoria quadripinnata (Atala \& Parra, unpublished data). Microsite's characteristics (moisture, light, nutrients) could allow $D$. dendroides to occur in relatively stable microenvironmental conditions along its latitudinal distribution. Hence, microsite characteristics could result in some degree of buffering from the latitudinal environmental changes. This could help explain the lack of population differences in the time at which the $50 \%$ of the $\mathrm{F}_{\mathrm{v}} / \mathrm{F}_{\mathrm{m}}$ was reached.

Our results suggest that this moss species can tolerate drought stress and desiccation and is able to recover from desiccation at very low water potentials. Mechanisms such as recovery of water content, quantum efficiency $\left(\mathrm{F}_{\mathrm{v}} / \mathrm{F}_{\mathrm{m}}\right)$, photosynthetic pigment and chloroplast ultrastructure, as well as prevention of damage to the plasma membrane have been related to the above DT (Sherwin \& Farrant 1996). Additionally, both populations are exposed to different rainfall (amount and distribution) over the year (Di Castri \& Hajek 1976, Parra et al. 2012). These sustained conditions over time could have resulted in the formations of ecotypes, although phenotypic plasticity in these physiological traits cannot be ruled out.

The ecophysiology of Chilean moss species is largely understudied. Studies have focused mainly on systematic and some aspects of their ecology (i.e. Larraín et al. 2011). Our results show that a dendroid moss of Chile can tolerate desiccation and recovers after rehydration. The interpopulation differences in this functional mechanism could help explain the latitudinal distribution of this moss species. Many populations of this moss species experience seasonal desiccation in the summer, when precipitation is scarce (Di Castri \& Hajek 1976). Individuals in the northern-most populations can survive up to 20-30 days without rain in the summer (personal observation). Other populations further south could experience freeze-induced drought during the winter due to snowfall and low temperatures. Light could be another factor influencing the functional response to desiccation between populations since Contulmo and Katalapi individuals differ in their light niche (Atala \& Parra, unpublished data).

There are few physiological and ecological studies on dendroid mosses despite their particular structure and the evolutionary consequences it may have. Future studies on $D$. dendroides could address how long plants can survive in a desiccated state and the physiological and biochemical mechanisms underlying this capacity. This knowledge could have important biotechnological and economical applications in the future. 


\section{ACKNOWLEDGEMENTS}

We would like to thank CONAF Araucanía and the Staff at Monumento Natural Contulmo for technical support and field assistance. We also thank Dr. Luis Corcuera for lodging and assistance at Katalapi Park. We would like to thanks two anonymous reviewers whose comments greatly improved this manuscript.

\section{REFERENCES}

AlPERT, P. 2000. The discovery, scope, and puzzle of desiccationtolerance in plants. Plant Ecology 151: 5-17.

Alpert, P. 2005. The limits and frontiers of desiccation-tolerant life. Integrative and Comparative Biology 45: 685-695.

Atala, C. 2011. Water transport and gas exchange in the nonvascular plant Dendroligotrichum dendroides (Brid. ex Hedw.) Broth. (Polytrichaceae, Bryophyta). Gayana Botánica 68(1): 89-92.

Atala, C. \& J.F. Alfaro. 2012. Vascular architecture of the dendroid antipodean moss Dendroligotrichum dendroides (Brid. ex Hedw.) Broth. (Polytrichaceae). Journal of Bryology 34: 277-280.

BECKETT, R.P. 2001. ABA-induced tolerance to ion leakage during rehydration following desiccation in the moss Atrichum androgynum. Plant Growth Regulation 35: 131-135.

Beckett, R.P., Z. Csintalan \& Z. Tuba. 2000. ABA treatment increases both the desiccation tolerance of photosynthesis, and nonphotochemical quenching in the moss Atrichum undulatum. Plant Ecology 151: 65-71.

Cruz de Carvalho, R., M. Catalá, J. Marques da Silva, C. Branquinho \& E. Barreno. 2012. The impact of dehydration rate on the production and cellular location of reactive oxygen species in an aquatic moss. Annals of Botany 110: 1007-1016.

Cruz de carvalho, R., C. Branquinho, \& J. Marques da Silva. 2011. Physiological consequences of desiccation in the aquatic bryophyte Fontinalis antipyretica. Planta 234: 195-205.

Cruz de Carvalho, R., A.B. Silva, R. Soares, A. Almeida, A.V. Coelho, J. Marques da Silva \& C. Branquinho. 2014. Differential proteomics of dehydration and rehydration in bryophytes: evidence towards a common desiccation tolerance mechanism. Plant, Cell \& Environment (in press).

Csintalan, Z., Z. Takács, M.C.F. Proctor, H.K. Lichtenthaler \& Z. TuBA. 1998. Desiccation and rehydration responses of desiccation-tolerant moss and lichen species from a temperate semidesert grassland. Journal of the Hattori Botanical Laboratory 84: 71-80.

Cui, S., J. Hu, S. Guo, J. Wang, Y. Cheng, X. Dang, L. Wu \& Y. He. 2012. Proteome analysis of Physcomitrella patens exposed to progressive dehydration and rehydration. Journal of Experimental Botany 63: 711-726.

CuI, X., S. Gu, J. Wu \& Y. TANG. 2009. Photosynthetic response to dynamic changes of light and air humidity in two moss species from the Tibetan Plateau. Ecological Research 24: 645-653.
Di CAstri, F. \& E.R. HaJek. 1976. Bioclimatología de Chile. Editorial de la Universidad Católica de Chile, Santiago, Chile. 129 pp.

He, S. 1998. A checklist of the mosses of Chile. Journal of the Hattori Botanical Laboratory 85: 103-189.

Kappen, L. \& F. Valladares. 2007. Opportunistic growth and desiccation tolerance: the ecological success of poikilohydrous autotrophs. In: F.I. Pugnaire \& F. Valladares (eds.), Functional Plant Ecology, $2^{\text {nd }}$ edition, pp. 67-100. CRC Press, Inc., Boca Raton, Florida, USA.

Lambers, H., F.S. Chapin III \& T.L. Pons. 2008. Plant physiological ecology, $2^{\text {nd }}$ edition. Springer Science + Business Media, LCC, NY, USA. 604 pp.

LARRAÍn, J., D. QuANDT \& J. MuÑoz. 2011. Bucklandiella araucana (Grimmiaceae), a new species from Chile. The Bryologist 114(4): 732-743.

Longton, R.E. 1981. Physiological ecology of mosses. In: R.J. Taylor \& S.E. Leviton (eds.), The mosses of North America, pp. 77-113. American Academy of Science, Pacific Division, Washington, USA.

Lüttge, U., S.T. Meirelles \& E.A. De Mattos. 2008. Strong quenching of chlorophyll fluorescence in the desiccated state in three poikilohydric and homoiochlorophyllous moss species indicates photo-oxidative protection on highly light-exposed rocks of a tropical inselberg. Journal of Plant Physiology 165: 172-81.

Maxwell, K. \& G.N. Johnson. 2000. Chlorophyll fluorescence - a practical guide. Journal of Experimental Botany 51: 659668.

Oliver, M.J. \& J.D. Bewley. 1997. Desiccation-tolerance in plant tissues. A mechanistic overview. Horticultural Review 18: 171-214.

Oliver, M.J. 1996. Desiccation tolerance in vegetative plant cells. Physiologia Plantarum 97: 769-787.

Oliver, M.J., Z. Tuba \& B.D. Mishler. 2000. The evolution of vegetative desiccation-tolerance in land plants. Plant Ecology 151: 85-100.

Oliver, M.J., A.J. Wood \& P. O’Mahony. 1998. "To dryness and beyond" - preparation for the dried state and rehydration in vegetative desiccation-tolerant plants. Plant Growth Regulation 24: 193-201.

Parra, M.J., K. Acuña, L. Corcuera, \& R. Rodríguez. 2012. Presencia de la familia Hymenophyllaceae (Pteridophyta) en el Parque Katalapi, Cordillera de Quillaipe, Provincia de Llanquihue, Chile. Gayana Botánica 69(2): 384-387.

Pressel, S. \& J.G. Duckett. 2010. Cytological insights into the desiccation biology of a model system: moss protonemata. New Phytologist 185: 944-63.

Proctor, M.C.F. 1981. Physiological ecology of Bryophytes. Advances in Bryology 1: 79-166.

Proctor, M.C.F. 2000. Physiological Ecology. In: A.J. Shawn \& B. Goffinet (eds.), Bryophyte Biology, pp. 225-247. Cambridge University Press, Cambridge, UK.

Proctor, M.C.F. 2001. Patterns of desiccation tolerance and recovery in bryophytes. Plant Growth Regulation 35: 147156.

Proctor, M.C.F. 2010. Recovery rates of chlorophyll-fluorescence parameters in desiccation-tolerant plants: fitted logistic curves as a versatile and robust source of comparative data. Plant Growth Regulation 62: 233-240. 
Proctor, M.C.F., R. Ligrone, \& J.G. Duckett. 2007a. Desiccation tolerance in the moss Polytrichum formosum: Physiological and fine-structural changes during desiccation and recovery. Annals of Botany 99: 75-93.

Proctor, M.C.F., Z. Nagy, Z. Csintalan \& Z. TaKács. 1998. Water-content components in bryophytes: Analysis of pressure-volume curves. Journal of Experimental Botany 49: $1845-1854$.

Proctor, M.C.F., M.J. Oliver, A.J. Wood, P. Alpert, L.R. Stark, N.L. Cleavitt \& B.D. Mishler 2007b. Desiccation tolerance in Bryophytes: a review. The Bryologist 110: 595-621.

Proctor, M.C.F. \& V.C. Pence. 2002. Vegetative tissues: bryophytes, vascular resurrection plants and vegetative propagules. In: M. Black \& H.W. Pritchard (eds.), Desiccation and survival in plants: drying without dying, pp 207-237. CABI Publishing, Wallingford, UK.

Rascio, N. \& N. LA Roca. 2005. Resurrection plants: The puzzle of surviving extreme vegetative desiccation. Critical Reviews Plant Science 24: 209-225.

Sherwin, H.W. \& J.M. FarRant. 1996. Differences in rehydration of three desiccation-tolerant angiosperm species. Annals of Botany 78: 703-710.

Stark, L.R., J.L. Greenwood, J.C. Brinda \& M.J. Oliver. 2013. The desert moss Pterygoneurum lamellatum exhibits inducible desiccation tolerance: effects of rate of drying on shoot damage and regeneration. American Journal of Botany 100: 1522-1531.

Tuba, Z., M.C.F. Proctor \& Z. Csintalan. 1998. Ecophysiological response of homoichlorophyllous and poikilochlorophyllous desiccation tolerant plants: a comparison and an ecological perspective. Plant Growth Regulation 24: 211-217.

Waite, M. \& L. Sack. 2010. How does moss photosynthesis relate to leaf and canopy structure? Trait relationships for 10 Hawaiian species of contrasting light habitats. New Phytologist 185: 156-72.

Wang, X.Q., P.F. Yang, Z. Liu, W.Z. Liu, Y. Hu, H. Chen, T.Y. Kuang, Z.M. Pei, S.H. Shen \& Y.K. He. 2009. Exploring the mechanism of Physcomitrella patens desiccation tolerance through a proteomic strategy. Plant Physiology 149: 1739-1750.

Recibido: 18.10 .13

Aceptado: 15.01.14 